


\section{CALAMOHERPE ARUNDINACEA.}

\section{Reed Warbler.}

Motacilla arundinacea, Lightf. in Phil. Trans., vol. lxxv. p. 8. pl. I.

Sylvia arundinacea, Penn. Brit. Zool., vol. i. p. 520.

Curruca arundinacea, Flem. Brit. Anim., p. 69.

Salicaria arundinacea, Selby, Ill. Brit. Orn., vol. i. p. 203.

Turdus arundinaceus minimus, Sepp, Vog., t. p. 101.-Id. p. 97, nest.

Calamoherpe arundinacea, Boie, Bonap. Consp. Gen. Av., tom. i. p. 285.

Sylvia strepera, Vieill.

Acrocephalus arundinaceus, Rüpp.

dumetorum, Blyth, Journ. Asiat. Soc. Beng., vol. xviii. p. 815 ?

Calamodyta arundinacea, Gray, List of Gen. and Subgen. of Birds in Brit. Mus., p. 33.

Although somewhat locally distributed, the Reed Warbler must rank as one of the commonest of the British birds; it occurs, however, less frequently in the western than in the eastern counties; neither does it proceed so far north as to be included among the birds of Scotland, and I have no reliable evidence that it has ever been found in Ireland. Mr. Rodd mentions it in his List of Cornish Birds, but adds that it is rare and very local. It is especially abundant on the banks of the Thames from Oxford to Loudon; it is equally numerous on the rivers Kennet and Colne, and it also frequents all the fluviatile districts of Sussex, Kent, Essex, Suffolk, and Norfolk. All round and even within the Metropolis many pairs annually breed; and at the moment I am writing (July 4, 1862), two pairs, at least, with their nests and young, may be seen in the lilac-trees of the Zoological Society's Gardens in the Regent's Park. On the continent of Europe, Holland appears to be its chief place of resort ; it also frequents France and all the central countries. Italy, Turkey, Asia Minor, and the whole of the Peninsula of India, I believe to be within the range of its migrations. The Indian birds have had the name of dimetorum applied to them by Mr. Blyth; but, on a careful comparison of specimens killed in Europe with others from India, I am unable to detect sufficient difference to induce me to regard them as distinct species. On the Thames and its tributaries it is generally associated with the Sedge Warbler in the same ait, patch of willows, or bed of rushes, the two species living in harmony, and competing with each other, both night and day, in the volubility with which they pour forth their songs, which bear so great a resemblance that it requires a very nice ear to distinguish the one from the other.

Mr. Selby states that "its song is varied and pleasing, with fewer of the harsh notes that prevail in that of the Sedge Warbler, but is delivered in the same hurried manner ;" and Mr. Sweet says that he had a male bird that sung occasionally all the winter. The song was very loud and variable, consisting of a great number of notes, and sung with many changes of voice, so diversified as to resemble the song of several different birds. "Its ordinary note," says the Rev. F. O. Morris, " is rapidly hurried, harsh, loud, garrulous, and unmusical, uttered almost incessantly, especially when its nest is in any danger-a mere 'kurrrrrr.' It has been likened, by J. G. Bonney, Esq., of Rugeley in Staffordshire, to the words 'chree, que, treet,' repeated without any order."

The incessant babbling made by numbers of this bird and the Sedge Warbler at sunrise on the banks of the Thames is beyond my power to describe. Those who have a sufficient love of nature to leave their beds at three o'clock on a fine July morning will be rewarded by a concert of which, until heard, they can have no conception.

Although naturally somewhat recluse, or evincing a preference for the thickest part of the coverts, it is by no means shy, - at least, I have never found it so. Its nest, without the slightest artifice, is placed on any exposed fork of an overhanging willow; or supported (as it very frequently is) between three or four adjoining stalks of rush; it will be seen, therefore, that the site of the nest is somewhat varied: it is always larger and more deeply cupped than that of the Sedge Warbler; and the eggs, also, are much more strongly blotched. That two birds, generically distinct, should be so similar in habits and style of colouring as the Sedge and Reed Warblers is very singular; yet so it is. During flight, while singing or threading the reeds, a close inspection is necessary before we can say with certainty which of the two birds has attracted our attention; on a careful examination, however, it will be seen that the Reed Warbler is of larger size, and of a nearly uniform colour; and that the Sedge Warbler has a conspicuous stripe of buffy white over the eye, and the head and upper surface longitudinally streaked and blotched with black. From the 15th of April to the first week in May is the time at which these birds arrive in all the above-mentioned localities. The same stimulus affects both alike: both spend the winter in Africa, and the summer in England; one of them 
is universally dispersed, the other locally. They breed in close contiguity; yet they never intermarry, but live and perform all their functions independently of each other.

It will be noticed that the arrival of the bird in spring is somewhat late. It is not, indeed, until the trees are in leaf, and the herbage is fully developed, that it appears. Aquatic insects and their larvæ are, I believe, the principal food of the Reed Warbler.

I have already mentioned that the site of the nest is somewhat varied, and I may now add that the materials of which it is composed are considerably diversified; and, in confirmation of this assertion, I append the descriptions of three nests, the first by my late friend, Mr. Yarrell, and the other two by myself.

"The nest of this bird is very singularly constructed and sustained : that from which the vignette at the end of this paper" (Brit. Birds, vol. i. p. 273) "was drawn, was supported between four reed-stems, and was taken from a bed of reeds on the side of the Thames, the surface-soil of which was covered by water at every tide, or twice in each twenty-four hours. It is formed of the seed-branches of the reeds and very long grass, wound horizontally round and round, including four upright reeds in the substance; thus forming, with a little wool, the sides of the nest, which frequently measures five inches in depth on the outside, three inches in breadth across the top, and often three inches deep inside. The lining is formed of very fine grass and long hairs. The nest is made so deep that the eggs do not roll out when the supporting reeds are waved by the wind; and Montagu observes that he has seen the bird sitting on her nest when every gust forced it almost to the surface of the water."

A nest taken by me at Maidenhead on the 24th of May, 1856, was interwoven between four of the upper stems of a willow; it was rather deep, and chiefly composed of a fine kind of water-weed, dried grass, and a little moss, with a few patches of wool placed here and there on the outside; the interior was solely lined with fine dried grasses.

Another nest taken from a similar situation at Formosa, near Cookham, in June 1860, was almost entirely composed of the downy, cotton-like substance of the common willow, compactly matted together with a little dried grass, and lined with the last-mentioned material. It contained four eggs, the ground-colour of which was delicate olive-grey, beautifully marked with blotches of brownish olive. It would seem that the eggs vary in hue, since Mr. Yarrell describes them as being "of a greenish-white colour, spotted and freckled with ash-green and light brown;" he adds that they are nine lines in length by six and a half in breadth.

So uniform is the plumage of the sexes in winter and summer, that the description of one is characteristic of both. The young, which are hatched in July, assume the adult colouring at a very early age, and soon quit the nest, hanging and clinging with perfect security among the reeds by means of their very sharp claws.

The head, neck, all the upper surface, wings, and tail olive-brown, the primaries and tail-feathers being somewhat darker; above the eye an obscure mark of buffy white; chin, throat, and centre of the abdomen buffy white; flanks and under tail-coverts pale buff; upper mandible deep olive-black; under mandible and a very narrow line at the base of the gonys of the upper one very delicate flesh-colour; irides wood-brown; legs and feet dull greenish black, the soles of the latter sulphur-yellow.

In a young bird killed on the 17 th of September, the upper mandible was dark olive, except the gonys, which, with the whole of the under mandible, was white, very slightly tinged with pink; legs dull olivegreen; thick and fleshy soles of the feet yellow; eye-stripe conspicuous buff.

The Plate represents the two sexes of the natural size. The plants are the Phragmites communis and Nymphaca alba. 


\section{$2 \mathrm{BHL}$ Biodiversity Heritage Library}

Gould, John. 1873. "Reed-Warbler, Calamoherpe arundinacea [PI. 73]." The birds of Great Britain 2, -. https://doi.org/10.5962/p.323887.

View This Item Online: https://www.biodiversitylibrary.org/item/221554

DOI: https://doi.org/10.5962/p.323887

Permalink: https://www.biodiversitylibrary.org/partpdf/323887

\section{Holding Institution}

Smithsonian Libraries

\section{Sponsored by}

Biodiversity Heritage Library

\section{Copyright \& Reuse}

Copyright Status: Public domain. The BHL considers that this work is no longer under copyright protection.

This document was created from content at the Biodiversity Heritage Library, the world's largest open access digital library for biodiversity literature and archives. Visit BHL at https://www.biodiversitylibrary.org. 